\title{
Utilizing selective chlorination to synthesize new triangulenium dyes with redshifted absorption and emission
}

\author{
Jesper Dahl Jensen, Niels Bisballe, Laura Kacenauskaite, Maria Storm Thomsen \\ and Bo W. Laursen*
}

Nano-Science Center and Department of Chemistry, University of Copenhagen, Universitetsparken 5, 2100 Copenhagen Ø (Denmark),*E-mail: bwl@ nano.ku.dk

\begin{abstract}
Access to functionalization of a new site in the triangulenium core structure has been achieved at an early stageby chlorination with N-chlorosuccinimide (NCS), giving rise to two new triangulenium dyes (1 and 2). By introducing the chlorine functionalities in the acridinium precursor, positions complementary to those previously accessed by electrophilic aromatic substitution of the dyes are functionalized. The chlorination is highly selective giving only one regioisomer for both mono- and dichlorination. For the monochlorinated acridinium compound a highly selective ring-closing reaction was discovered generating only a single regioisomer of the cationic [4]helicene product. This discovery aspired further investigations into the mechanism of [4]helicene formation and to the first isolation of the previously proposed intermediate of the two-step $\mathrm{S}_{\mathrm{N}} \mathrm{Ar}$ reaction key to all aza bridged triangulenium and helicenium synthesis. The fully ring closed mono- and di-chlorinated triangulenium dyes $\mathbf{1}$ and $\mathbf{2}$ show a redshift in absorption and emission relative to the non-chlorinated analogues, while still maintaining relative high quantum yields of $36 \%$ and $41 \%$, and long fluorescence lifetimes of $15 \mathrm{~ns}$ and $16 \mathrm{~ns}$, respectively.
\end{abstract}

\section{Introduction:}

Triangulenium dyes and their helicene congeners are highly stabilized carbenium systems with attractive fluorescence properties (Figure 1). ${ }^{1-3}$ High chemical and photochemical stability is key to their applications in both sensors and photocatalytic processes. ${ }^{4-9}$ Uniquely long fluorescence lifetime of the azadioxa- and diazaoxa-triangulenium dyes $\left(\mathrm{ADOTA}^{+}\right.$and DAOTA $\left.^{+}\right)\left(\tau_{f 1} \approx 20 \mathrm{~ns}\right)$ enables elimination of auto fluorescence by time-gated imaging and widens the measuring range in polarization assays. ${ }^{10-13}$ The long fluorescence lifetime and good quantum yields $(60-80 \%)$ of the ADOTA $^{+}$and DAOTA ${ }^{+}$ triangulenium dyes make the scaffolds obvious targets for modifications aiming at tuning the optical properties. $\mathrm{ADOTA}^{+}$and $\mathrm{DAOTA}^{+}$ fluoresce at $560 \mathrm{~nm}$ and $590 \mathrm{~nm}$ respectively. ${ }^{14-15}$

Shifting the absorption and emission further to the red side of the spectrum is highly attractive for imaging applications and have been successfully achieved by replacing one of the oxygen bridges by saturated or unsaturated carbon bridges, yielding dyes with emission between $580 \mathrm{~nm}$ and $652 \mathrm{~nm} .{ }^{16-}$ ${ }^{17}$ However, in all cases these modifications come at the price of enhanced non-radiative deactivation rates resulting in somewhat reduced quantum yields (30-60\%) and lifetimes (12-18 ns).

These findings emphasize the significant challenges in designing red emitters with long fluorescence lifetimes and high quantum yields. In 
<smiles></smiles>

1a

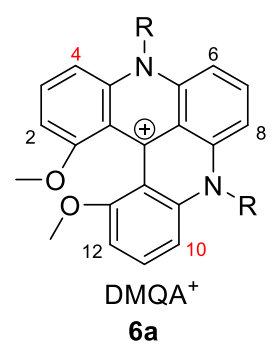<smiles>[R]N1c2ccccc2OC23C(=C)C=CC=C2Oc2cccc1c23</smiles><smiles>[R]N1c2cccc(OC)c2C(c2c(OC)cccc2OC)c2c(OC)cccc21</smiles>
$\mathrm{ADOTA}^{+}, \mathrm{DAOTA}^{+}$and their precursors $\mathrm{TMAcr}^{+}(\mathbf{3})$ and $\mathrm{DMQA}^{+}$. For specific derivatives 1a, 2a, and $\mathbf{6 a}: \mathrm{R}=$ propyl.

a different approach a range of functional groups were introduced into the DAOTA ${ }^{+}$system (1a) by electrophilic substitution exclusively in the 9 position (Figure 1). ${ }^{18}$ The same selectivity for the aromatic ring with the most nitrogen bridges was also found for the helicene congeners, like e.g. $\mathrm{DMQA}^{+}(\mathbf{6 a})$ reacting in the analogous 6 position (Figure 1). ${ }^{19}$ In all cases where the introduced functional groups caused a redshift this was however unfortunately accompanied by significant
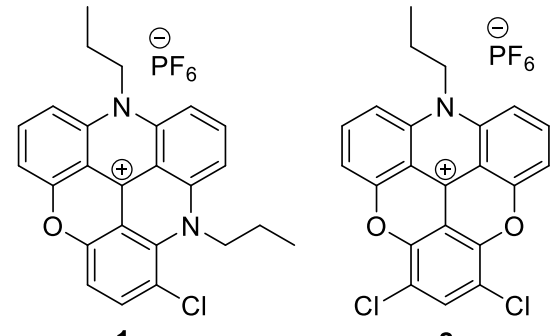

Figure 1. Molecular structure of chlorinated targets, monochlorinated DAOTA ${ }^{+}(\mathbf{1})$ and dichlorinated $\mathrm{ADOTA}^{+}$ (2).

quenching of the fluorescence. In this study we aim at widening the chemical diversity and tuning the optical properties of $\mathrm{ADOTA}^{+}$and $\mathrm{DAOTA}^{+}$dyes by investigating chlorination, specifically targeting positions of the $\mathrm{ADOTA}^{+}$and DAOTA $^{+}$ chromophores not previously investigated. We here report the synthesis and optical properties of 3-chloro-DAOTA (1) and 5,7-dichloro-ADOTA (2) (Figure 2).
Figure 2. General structures in the triangulenium family,

\section{Results and Discussion:}

Synthesis. To circumvent the above-mentioned regioselectivity of the final dye systems we turned our attention to an early stage modification of the common acridinium precursor of the $\mathrm{ADOTA}^{+}$and DAOTA $^{+}$systems. ${ }^{20}$ The readily available propyl acridinium compound $\mathbf{3}$ was mono- and dichlorinated selectively in the 3' bad 5' positions of the 9-dimethoxyphenyl ring of 3 by addition of $\mathrm{N}$ chlorosuccinimide (NCS) in acetonitrile (Scheme $1)$.

This selectivity is easily understood when<smiles>CCCN1c2cccc(OC)c2C(c2c(OC)ccc(Cl)c2OC)c2c(OC)c(Cl)cc([P+](=O)[O-])c21</smiles><smiles>CCCN1c2cccc(OC)c2C(c2c(OC)cccc2OC)c2c(OC)cccc21</smiles><smiles>CCCN1c2cccc(OC)c2C(c2c(OC)cccc2OC)c2c(OC)cccc21</smiles>

Scheme 1. Synthetic scheme for the formation of $\mathbf{4}$ and $\mathbf{5}$. a: (1) $\mathrm{NCS}, \mathrm{MeCN}, 55^{\circ} \mathrm{C}, 26 \mathrm{~h}$, (2) NCS, $\mathrm{MeCN}, 55^{\circ} \mathrm{C}, 4 \mathrm{~h}, 54$ $\%$, b: NCS, $\mathrm{MeCN}, 55^{\circ} \mathrm{C}, 25 \mathrm{~h}, 97 \%$.

considering that the electron rich dimethoxyphenyl group is perpendicular to and decoupled from the electron deficient acridinium system. ${ }^{20-21}$ Mono chlorination was achieved using 1.06 equivalents of NCS. Reaction was carried out in a nitrogen purged sealed tube at $55^{\circ} \mathrm{C}$ for $25 \mathrm{~h} .5$ was isolated by precipitation and no further purification was needed giving an excellent yield of $97 \%$. The addition of two chlorines was achieved with almost stoichiometric control using only 0.5 equivalent of excess NCS. The moderate yield of $\mathbf{4}(54 \%)$ is attributed to formation of the reduced $9 \mathrm{H}$-acridine with a hydride added to the central carbon. ${ }^{22}$ Based on ${ }^{1} \mathrm{H}-\mathrm{NMR}$ intensities of the crude product approximately $30 \%$ of the product is reduced. Careful purification of $\mathbf{4}$ is of great importance, since separation of byproducts with one or three chlorines is relatively easy at this stage, but very difficult after formation of the planar triangulenium compounds.

Ring closure of the dichlorinated acridinium 4 by heating in molten pyridine hydrochloride $(\mathrm{Pyr} \mathrm{HCl})$ gave 5,7-dichloro-ADOTA ${ }^{+}$(2) in high yield (Scheme 2). 


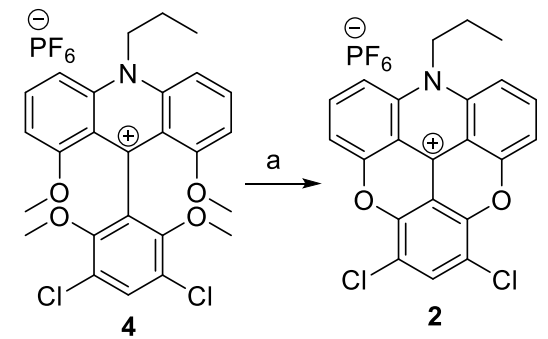

Scheme 3. Synthetic route for dichlorinated $\mathrm{ADOTA}^{+} \mathbf{2}$. a: Pyr $\mathrm{HCl}, 200^{\circ} \mathrm{C}, 30 \mathrm{~min}, 70 \%$.

Synthesis of the DAOTA ${ }^{+}$system from the mono chlorinated acridinium $\mathbf{5}$ is performed in two steps (Scheme 3). First, the second nitrogen bridge is introduced via a double nucleophilic aromatic substitution $\left(\mathrm{S}_{\mathrm{N}} \mathrm{Ar}\right)$ with propyl amine replacing two methoxy groups yielding the [4]helicene cation 6. Remarkably, this reaction is highly selective and produces only $\mathbf{6}$ where the chlorine is located ortho to the newly formed nitrogen bridge (see SI for 2D NMR assignment).

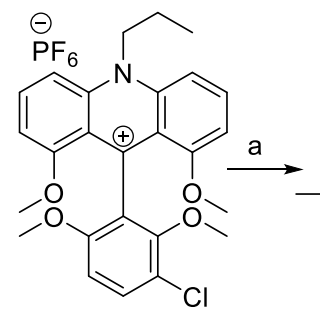

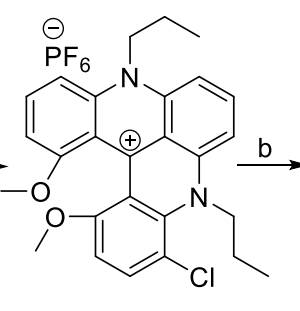

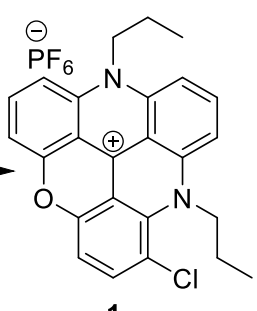

Scheme 2. Synthetic route for monochlorinated DAOTA ${ }^{+} \mathbf{1}$. a: Propylamine, $\mathrm{MeCN}, 100^{\circ} \mathrm{C}, 2 \mathrm{~h}, 39 \%$, b: $\mathrm{Pyr} \cdot \mathrm{HCl}, 220^{\circ} \mathrm{C}$, $40 \mathrm{~min}, 59 \%$.

The other possible regioisomer with chlorine para to the formed nitrogen is not observed at all. Later in the process a single crystal x-ray structure of $\mathbf{6}$ was obtained, which verified the assigned structure (see SI for structural details). The moderate yield for this step is again due to the formation of the corresponding reduced compound. This varies between $30-50 \%$ yield of the reduced form, based on NMR of crude samples from several reactions. Adding 6 to molten $\mathrm{Pyr} \mathrm{HCl}$ results in the last ring closure and $\mathrm{DAOTA}^{+}(\mathbf{1})$ is formed in acceptable yields (59\%).

The observed regioselectivity in the $S_{N} A r$ reaction with propylamine is intriguing since this is an absolute key step in all triangulenium and related helicenium syntheses and has not been reported previously. To investigate this reaction step further we ran the $S_{N} A r$ reaction at very mild conditions in the hope that we could observe the intermediate in this two-step substitution reaction and thereby elucidate the mechanism and the origin of the regioselectivity. The first step in the formation of $\mathbf{6}$ from 4 is a replacement of one methoxy group by the amine nucleophile. In this case, this can in principle lead to two different products (Figure 3) depending if this bimolecular $\mathrm{S}_{\mathrm{N}} \mathrm{Ar}$ reaction happens on the acridinium ring system leading to IM-1 or on the dimethoxyphenyl ring leading to IM-2.
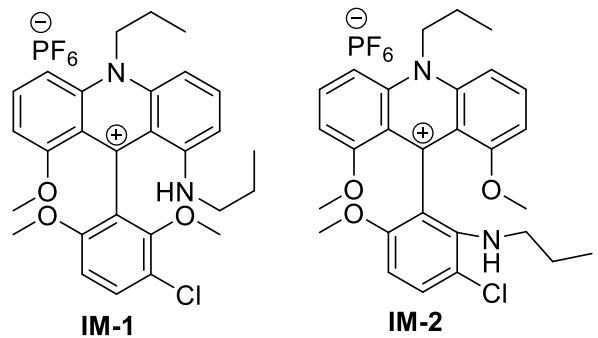

Figure 3. The structures of two possible intermediates (IM-1 and IM-2) in the synthesis of $\mathbf{6}$

The mild substitution reaction was followed over time with MALDI-TOF recording the relative intensity for each component (S28-29). This show that the intermediate is only present at a constant low level and the final product $\mathbf{6}$ is building up with the same rate as the starting material is consumed (Figure 4a). For comparison we ran the same mild substitution reaction with propylamine and the non-chlorinated acridinium compound 3 (S30). The results show that in this case the intermediate is building up in concentration (Figure $4 \mathrm{~b}$ ) and that the final product $(\mathbf{6 a})$ is formed at a much lower rate than for the chlorinated compound. The intermediate was isolated, and its structure identified by NMR (S23-27), as the nonchlorinated IM-1 analogue IM-1a (Figure 5). This is the first time that an intermediate of the two-step $\mathrm{S}_{\mathrm{N}} \mathrm{Ar}$ ring closure reactions of helicenes and triangulenium dyes has been identified and isolated. The isolated intermediate confirms the originally proposed mechanism of a bimolecular $\mathrm{S}_{\mathrm{N}} \mathrm{Ar}$ reaction controlled by the electron deficiency of the cationic reagents, ${ }^{20}$ which recently also was supported by theoretical calculations. ${ }^{23}$ 
a:

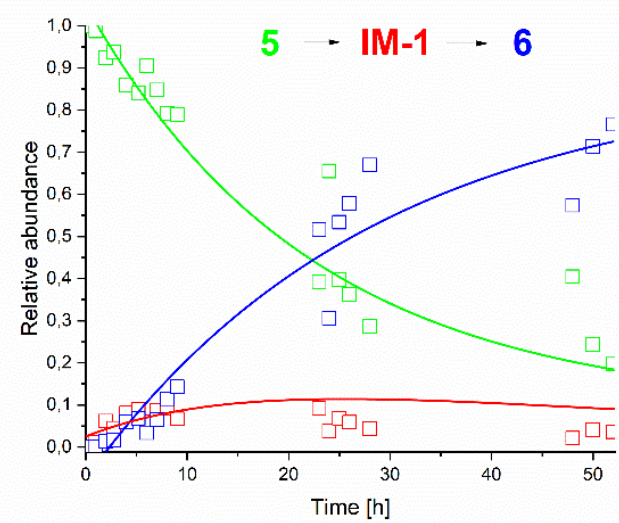

b:

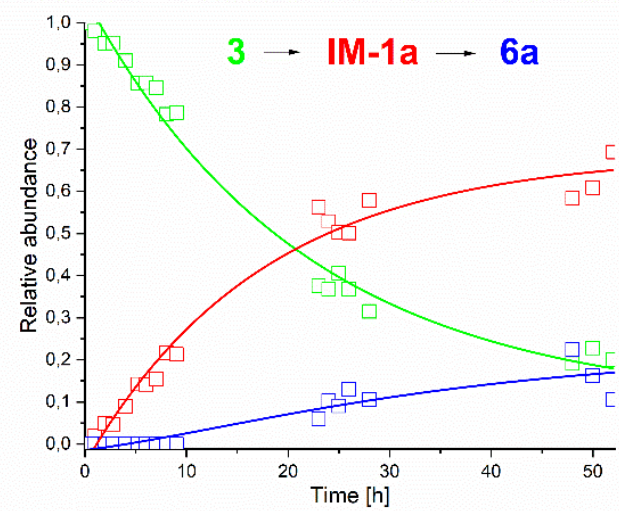

Figure 4: Kinetic experiments showing the relative abundance of the different constituents a: following the reaction of $\mathbf{5}$ with propylamine. Green $=\mathbf{5}$, red $=\mathbf{I M - 1}$ or IM-2, blue $=6$. b: following the reaction of 3 with propylamine, Green $=\mathbf{3}$, red $=\mathbf{I M}-1 \mathbf{a}$, blue $=\mathbf{6} \mathbf{a}$.

Fitting the consumption of the starting acridinium compounds $\mathbf{3}$ and $\mathbf{5}$ with an exponential decay (green traces in Figure 4), matching the pseudo first order kinetic conditions, yields rate constants of $21.6 \mathrm{~h}^{-1}$ and $22.3 \mathrm{~h}^{-1}$ for $\mathbf{3}$ and $\mathbf{5}$ respectively (See SI). The reaction rates of both compounds are almost identical, which strongly indicates that the first step in the reactions is the same and not influenced by the presence of the chlorine atom. This also means that IM-1 must be the intermediate

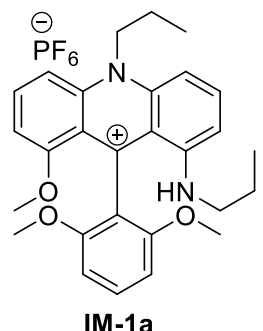

Figure 5. Molecular structure of isolated intermediate (IM1a) in the formation of $\mathbf{6}$ and that the selectivity leading to 6 originates in the second step of the reaction. From the kinetic data for formation of the ring closed [4] helicene products $\mathbf{6}$ and $\mathbf{6 a}$ (blue traces in Figure 4) we observe a highly increased reaction rate of the chlorinated dimethoxyphenyl group in comparison to the non-chlorinated one. Thus, the chlorine atom speeds up the intramolecular ring closure significantly, favoring reaction ortho to chlorine leading to the selective formation of $\mathbf{6}$. We tentatively assign the observed regio selectivity to steric effects. The chlorine atom pushes the ortho methoxy group out of the plane giving a larger area for the nucleophilic amine to attack and undergo intramolecular nucleophilic aromatic substitution.

Structure and optical properties. Isolation of the amino-acridinium intermediate IM-1a (Figure 5) allows for an interesting comparison of the electronic spectra with those of the precursor 3 and the final ring closed [4]helicene 6a as shown in Figure 6.

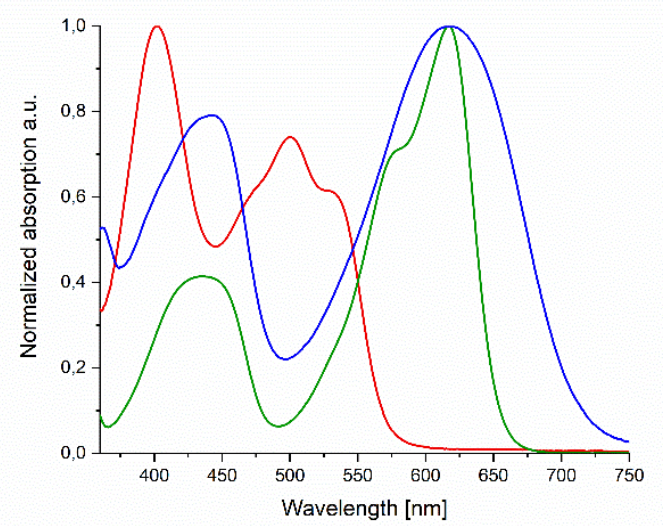

Figure 6. Normalized absorption spectra of $\mathbf{3}$ (red), $6 \mathbf{a}$ (green) and IM-1a (blue) in $\mathrm{CH}_{2} \mathrm{Cl}_{2}$

[4]- and [6]-helicenes of the $\mathrm{DMQA}^{+}$type have been extensively studied. A key feature is the characteristic redshifted absorption and emission compared to 3. Inspection of the absorption spectrum of IM-1a clearly shows that the fundamental chromophoric unit responsible for optical properties of $\mathrm{DMQA}^{+}$is the 1aminoacridinium system present already in IM-1. However, the $\mathrm{S}_{0} \rightarrow \mathrm{S}_{1}$ transition is broadened and no fluorescence is observed, likely due to the higher flexibility of the amino-acridinium system in IM- 
1a compared to $\mathrm{DMQA}^{+}$and the quenching ability of 2,6-dimethoxyphenyl.

The optical properties of the new chlorinated triangulenium dyes $\mathbf{1}, \mathbf{2}$ and their non-chlorinated reference compounds were measured in $\mathrm{CH}_{3} \mathrm{CN}$ solutions. The absorption, excitation and emission spectra of all of the compounds can be found in Supporting Information. Absorption and emission spectra of $\mathrm{ADOTA}^{+} \mathbf{2}$ and $\mathbf{2 a}$ are shown in Figure 7. The spectroscopic data are listed in Table 1. A first observation for $\mathbf{2}$ is a redshift in absorption and emission of $15 \mathrm{~nm}$ and $14 \mathrm{~nm}$, respectively compared to 2a. The spectral shapes are also very similar indicating that chlorine does not affect the nature of the optical transitions of the dye to any large extent.

\begin{tabular}{|l|l|l|l|l|l|l|}
\hline Compound & $\begin{array}{l}\lambda_{\text {abs }} \\
{[\mathrm{nm}]}\end{array}$ & $\begin{array}{l}\lambda_{\mathrm{em}} \\
{[\mathrm{nm}]}\end{array}$ & $\Phi_{\mathrm{f}}{ }^{a}$ & $\begin{array}{l}\tau_{\mathrm{fl}} \\
{[\mathrm{ns}]}\end{array}$ & $\begin{array}{l}k_{f}{ }^{c} \\
10^{6} \\
{\left[\mathrm{~s}^{-1}\right]}\end{array}$ & $\begin{array}{c}k_{n r}{ }^{d} \\
10^{6} \\
{\left[\mathrm{~s}^{-1}\right]}\end{array}$ \\
\hline $\mathbf{1}$ & 572 & 598 & 0.36 & 14.7 & 24 & 44 \\
\hline $\mathbf{1 a}$ & 558 & 576 & $0.57(0.58)^{\mathrm{b}}$ & 20.1 & 28 & 21 \\
\hline $\mathbf{2}$ & 555 & 574 & 0.41 & 16.1 & 26 & 37 \\
\hline $\mathbf{2 a}$ & 540 & 560 & $0.64(0.69)^{\mathrm{b}}$ & 22.9 & 28 & 16 \\
\hline
\end{tabular}

Table 1. Photophysical properties of 1, 1a, 2 and 2 a in acetonitrile. ${ }^{a}$ Measured using Rhodamine $6 \mathrm{G}$ in absolute ethantol as the standard $\left(\Phi_{\mathrm{f}}=0.95\right)$ following $507 \mathrm{~nm}$ laser excitation. Refractive indices used: $\mathrm{MeCN}=1.34411 ; \mathrm{EtOH}=$ $1.36143\left(\right.$ from $\left.^{24}\right)$. ${ }^{b}$ In parentheses literature values from ${ }^{15} .{ }^{c} k_{f}$ $=\Phi_{\mathrm{f}} / \tau_{\mathrm{fl}} \cdot{ }^{\mathrm{d}} k_{n r}=\left(1 / \tau_{\mathrm{fl}}\right)-k_{f}$.

The molar absorption coefficients $\varepsilon_{\max }$ of $\mathbf{2}$ is also similar to that of $2 \mathbf{a}, 10090 \mathrm{M}^{-1} \mathrm{~cm}^{-1}$ and $9840 \mathrm{M}^{-}$ ${ }^{1} \mathrm{~cm}^{-1}$, respectively. ${ }^{25}$ This trend with general redshift of spectra and retention of absorption coefficients is also found for the mono chlorinated DAOTA derivative 1 compared to its non-

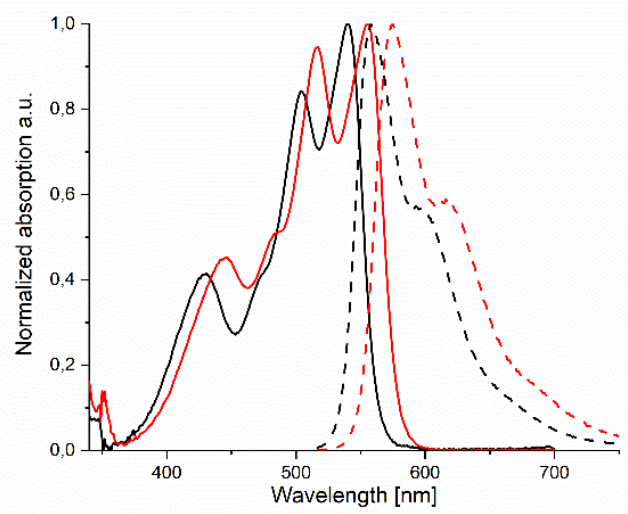

Figure 7. Normalized absorption and emission spectra for $\mathbf{2}$ and $\mathbf{2} \mathbf{a}$ in acetonitrile. chlorinated analogue 1a (Figure 8). In this case molar absorption coefficients $\varepsilon_{\max }$ are $13780 \mathrm{M}^{-}$ ${ }^{1} \mathrm{~cm}^{-1}$ and $14800 \quad \mathrm{M}^{-1} \mathrm{~cm}^{-1}$, respectively. ${ }^{20}$ Absorption and emission redshift by $12 \mathrm{~nm}$ and 21 $\mathrm{nm}$, respectively.

Fluorescence quantum yields in acetonitrile were measured for both the chlorinated compounds and

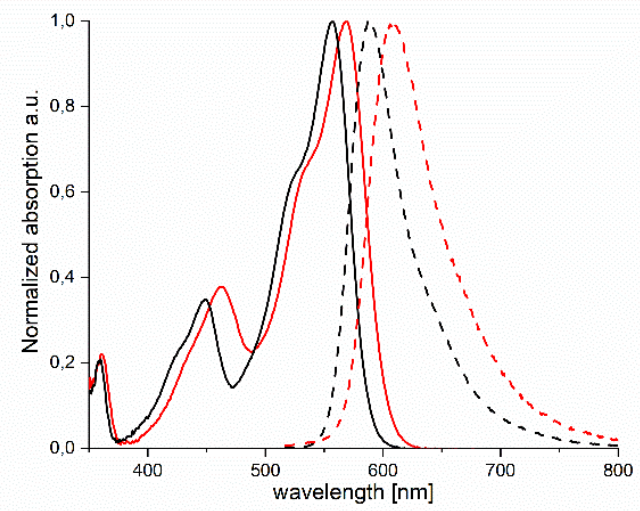

Figure 8. Normalized absorption and emission spectra for $\mathbf{1}$ and $1 \mathbf{a}$ in acetonitrile.

their known reference compounds. The values are listed in Table 1 and previously reported values given in parentheses. For both compounds the quantum yield drops by $1 / 3$ due to the chlorination, though still resulting in applicable $\Phi_{\mathrm{f}}=36 \%$ and $41 \%$ for $\mathbf{1}$ and $\mathbf{2}$, respectively. All four compounds show mono exponential fluorescence decays with lifetimes $\left(\tau_{\mathrm{fl}}\right)$ between 15 and $23 \mathrm{~ns}$. From the fluorescence lifetimes and quantum yields, rate constans of fluorescence $\left(k_{f}\right)$ and non-radiative deactivation $\left(k_{n r}\right)$ were determined (Table 1). This analysis clearly confirms that chlorination does not affect the radiative processes but leads to an approximate doubling of the non-radiative deactivation rates, which is responsible for the reduced quantum yields and lifetimes.

\section{Conclusion:}

Electrophilic mono and di chlorination of the acridinium precursor $\mathbf{3}$ demonstrates an early stage functionalization strategy giving access to new substitution patterns of cationic [4] helicenes of the $\mathrm{DMQA}^{+}$family and long fluorescence lifetime ADOTA $^{+}$and DAOTA $^{+}$dyes. Specifically, monochlorinated DAOTA 1 and dichlorinated 
ADOTA $^{+} \mathbf{2}$ were synthesized and photophysically characterized showing moderately redshifted emission accompanied by moderate drop in fluorescence quantum yields and fluorescence lifetimes. Isolation of the amino-acridine intermediate IM-1a provides the final experimental evidence for the reaction mechanism leading to formation of DMQA ${ }^{+}$type [4] helicenes and reveals the structural origin of its unique redshifted (600-700 $\mathrm{nm}$ ) chromophore system.

The early stage chlorination strategy can thus be used for fine tuning of spectral properties of both cationic helicenes and long fluorescence lifetime triangulenium dyes. We also expect that this strategy will be useful for tuning of redox potentials important for photocatalysis, organic hydride donors and electrogenerated chemiluminescence applications where these cationic dye systems recently have shown promising results. ${ }^{8-9,26-27}$ Finally, the chlorinated systems are obvious starting points for coupling reactions aiming for $\pi$-system extension. ${ }^{28-30}$

\section{Experimental section:}

Synthetic Methods and Materials. All chemicals and solvents were purchased from commercial suppliers and used as received, except for $\mathbf{3}$ which was synthesized as described in the litterature ${ }^{20}$. The NCS was newly bought and used without further purification. Mass spectra were recorded on an ESP-MALDI-FT-ICR instrument equipped with a $7 \mathrm{~T}$ magnet (The instrument was calibrated using sodium trifluoroacetate cluster ions prior to acquiring the spectra). ${ }^{1} \mathrm{H}$ and ${ }^{13} \mathrm{C}$-NMR spectra were acquired on a Bruker $500 \mathrm{MHz}$ instrument equipped with a (non-inverse) cryoprobe. All chemical shift values in both ${ }^{1} \mathrm{H}$ and ${ }^{13} \mathrm{C}$ NMR spectra are referenced to the residual solvent peak $\left(\mathrm{CD}_{3} \mathrm{CN} \delta \mathrm{H}=1.94, \delta \mathrm{C}=118.26\right.$; $)$. All ${ }^{13} \mathrm{C}-\mathrm{NMR}$ are APT spectra, and uneven numbers of protons attached are referred to with + , and even numbers of protons attached are referred to with -.

Spectroscopic Methods. The solvent used for spectroscopic measurements were of HPLC grade and used as received. The UV-vis absorption spectra were recorded on a Cary 300 UV-Vis double beam spectrophotometer (Agilent
Technologies, Santa Clara, USA) using pure solvent as the baseline. All spectra were recorded using $1 \mathrm{~cm}$ path length quartz cuvettes in $1 \mathrm{~nm}$ steps. The excitation spectra were recorded using a PTI QuantaMaster8075 (Horiba, Kyoto, Japan) system, using a xenon arc lamp as excitation source. The spectra were recorded at multiple wavelength, see SI, slits were $3 \mathrm{~nm}$ wide. The fluorescence lifetimes and emission spectra were recorded with a FluoTime 300 (PicoQuant, Berlin, Germany) system. The fluorescence decays were analyzed with the FluoFit software package. Data for the decay $\left(I_{f}(t)\right)$ were fitted by iterative reconvolution with a sum of exponentials:

$$
I_{f}(t)=\Sigma \alpha_{i} \exp \left(-\frac{t}{\tau_{i}}\right) \quad \text { eq. } 1
$$

In eq $1, \alpha_{\mathrm{i}}$ is the amplitude and $\tau_{\mathrm{i}}$ is the fluorescence lifetime of the $\mathrm{i}^{\text {th }}$ component. The samples were excited using a pulsed solid-state LDH-P-C-510 $\mathrm{nm}$ laser (excitation at $507 \mathrm{~nm}$ ). Fluorescence decay were recorded at $620 \mathrm{~nm}$. The instrument response function (IRF) was measured at the excitation wavelength using a dilute scattering suspension of Ludox. For all of the fluorescence measurements, the angle between the excitation and emission polarizers was set to $54.7^{\circ}$ (magic angle). All fluorescence quantum yields were determined by the relative method. The samples were excited by a pulsed solid-state laser at 507 $\mathrm{nm}$, and the quantum yields were determined with respect to rhodamine $6 \mathrm{G}$ in absolute ethanol $\left(\Phi_{\mathrm{f}}=0.95\right) .{ }^{31}$ The fluorescence measurements were performed in a $1 \mathrm{~cm}$ path length. For all quantum yield measurements, the absorbance was below 0.12 at the maximum of the lowest energy absorption band. All fluorescence spectra were corrected for the wavelength-dependent sensitivity of the detection system.

\section{1-Chloro-8,12-dipropyl-8,12-diaza-4-oxa triangulenium hexafluorophosphate}

In an Erlenmeyer flask (100 $\mathrm{mL})$, pyridine hydrochloride $(10 \mathrm{~g}, 87 \mathrm{mmol})$ was heated to $220^{\circ} \mathrm{C}$ until material solidified on the inside of the flask. The material was melted back into the flask using a heat gun, and 6 (142 mg, $0.238 \mathrm{mmol})$ was added in one portion upon stirring. The mixture was stirred for $40 \mathrm{~min}$ at $220^{\circ} \mathrm{C}$. Heating was 
removed and the mixture was allowed to reach ambient temperature. To the mixture aqueous $\mathrm{KPF}_{6}(\mathrm{aq})(0.2 \mathrm{M}, 100 \mathrm{~mL})$ was added and left stirring vigorously. The mixture was then transferred into aqueous $\mathrm{KPF}_{6}(\mathrm{aq})(0.2 \mathrm{M}, 300$ $\mathrm{mL})$. The aqueous phase was then extracted with DCM $(150 \mathrm{~mL})$. The organic layer was then washed with $10 \% \mathrm{NaOH}(\mathrm{aq})(1 \mathrm{M})$ in $\mathrm{KPF}_{6}(\mathrm{aq})$ $(0.2 \mathrm{M}, 100 \mathrm{~mL})$, and then washed with water. The organic solvent was then removed in vacuo. The solid was resolubilized in $\mathrm{MeCN}(5 \mathrm{~mL})$ and reprecipitated in $10 \% \mathrm{HCl}(\mathrm{aq})(1 \mathrm{M})$ in $\mathrm{KPF}_{6}(\mathrm{aq})$ $(0.2 \mathrm{M}, 100 \mathrm{~mL})$. The precipitate was isolated by filtration and washed with $\mathrm{Et}_{2} \mathrm{O}$. The formed solid was recrystallized in 9:1 $\mathrm{MeOH} / \mathrm{MeCN}$ (112 $\mathrm{mL} / \mathrm{g})$. Yield: $77.5 \mathrm{mg}(59 \%)$.

HR-MS (ESP) found: 401.1415. Calcd. for $\mathrm{C}_{25} \mathrm{ON}_{2} \mathrm{Cl}_{2} \mathrm{H}_{22}{ }^{+}: 401.1421$

${ }^{1} \mathrm{H}$ NMR $\left(500 \mathrm{MHz}\right.$, Acetonitrile- $\left.d_{3}\right) \delta 8.26(\mathrm{t}, J=8.6$ $\mathrm{Hz}, 1 \mathrm{H}), 8.15-8.06(\mathrm{~m}, 2 \mathrm{H}), 7.62(\mathrm{~d}, J=8.9 \mathrm{~Hz}, 1 \mathrm{H})$, $7.55(\mathrm{~d}, J=8.7 \mathrm{~Hz}, 1 \mathrm{H}), 7.52(\mathrm{~d}, J=8.6 \mathrm{~Hz}, 1 \mathrm{H}), 7.32$ (d, $J=8.1 \mathrm{~Hz}, 1 \mathrm{H}), 7.27(\mathrm{~d}, J=8.8 \mathrm{~Hz}, 1 \mathrm{H}), 4.75-4.68$ (m, 2H), $4.52-4.47(\mathrm{~m}, 2 \mathrm{H}), 2.12-2.08(\mathrm{~m}, 2 \mathrm{H}), 2.01$ -1.96 (m, 2H), 1.18 (t, $J=7.4 \mathrm{~Hz}, 3 \mathrm{H}), 1.03$ (t, $J=7.4$ $\mathrm{Hz}, 3 \mathrm{H})$.

${ }^{13} \mathrm{C}$ NMR (126 MHz, $\left.\mathrm{CD}_{3} \mathrm{CN}\right) \delta 152.98(-), 152.82(-)$, 144.05(-), 142.76(+), 141.70(-), 141.29(-), 140.89(+), 140.76(-), 139.81(+), 138.99(-), 114.65(-), 113.09(-), 111.36(+), 111.09(-), 110.44(+), 109.15(+), 108.93(-), $108.31(+), \quad 107.85(+), \quad 55.04(-), \quad 50.66(-), 22.95(-)$, 19.92(-), 11.11(+), 10.77(+).

\section{5,7-Dichloro-12-propyl-12-aza-4,8-}

dioxatriangulenium hexafluorophosphate (2) In an Erlenmeyer flask, pyridine hydrochloride (10 $\mathrm{g}, 87 \mathrm{mmol}$ ) was heated to $200^{\circ} \mathrm{C}$ until material solidified on the inside of the flask. The material was melted into the flask using a heat gun, and $\mathbf{4}$ (409.2 mg, $647.1 \mu \mathrm{mol})$ was added in one portion while stirring. The mixture was left stirring for 30 minutes, then heating was removed, and the mixture was allowed to reach ambient temperature. Water $(140 \mathrm{~mL})$ was added to the mixture which was then transferred into aqueous $\mathrm{KPF}_{6}(\mathrm{aq})(0.2 \mathrm{M}$, $150 \mathrm{~mL}$ ) and left stirring vigorously. The precipitate was isolated by filtration, washed with $\mathrm{Et}_{2} \mathrm{O}$ and then eluted off the filter using $\mathrm{MeCN}$ and concentrated in vacuo. The solid was solubilized in hot $\mathrm{MeCN}(39 \mathrm{~mL} / \mathrm{g})$ and then an equal amount of
EtOH was added. When the solution was boiling heating, was removed and the mixture was left to crystallize, yielding dark red crystals. Yield: 245 $\mathrm{mg}(70 \%)$.

${ }^{1} \mathrm{H}$ NMR $\left(500 \mathrm{MHz}\right.$, Acetonitrile- $\left.d_{3}\right) \delta 8.42-8.38(\mathrm{~m}$, $2 \mathrm{H}), 8.26(\mathrm{~s}, 1 \mathrm{H}), 7.94(\mathrm{~d}, J=9.0 \mathrm{~Hz}, 2 \mathrm{H}), 7.66(\mathrm{~d}, J=$ $8.1 \mathrm{~Hz}, 2 \mathrm{H}), 4.77-4.73(\mathrm{~m}, 2 \mathrm{H}), 2.08-1.99(\mathrm{~m}, 2 \mathrm{H})$, 1.19 (t, $J=7.4 \mathrm{~Hz}, 3 \mathrm{H})$.

${ }^{13} \mathrm{C}$ NMR (126 MHz, $\left.\mathrm{CD}_{3} \mathrm{CN}\right) \delta$ 153.35(-), 147.73(-), 142.25(+), 141.69(-), 140.66(-), 139.35(+), 117.06(-), 112.31(+), 110.72(+), 110.18(-), 108.31(-), 51.50(-), 20.89(-), 11.15(+).

HR-MS (ESP) found: 394.0397. Calcd. for $\mathrm{C}_{22} \mathrm{NO}_{2} \mathrm{Cl}_{2} \mathrm{H}_{14}{ }^{+}$: 394.0402 .

\section{9-(3,5-Dichloro-2,6-dimethoxyphenyl)-1,8- dimethoxy-10-propylacridinium hexafluorophosphate}

In a Pyrex tube $3(1.02 \mathrm{~g}, 1.80 \mathrm{mmol})$ was dissolved in anhydrous MeCN (4 mL). Then NCS $(538 \mathrm{mg}$, $4.03 \mathrm{mmol}$ ) dissolved in anhydrous $\mathrm{MeCN}$ (4.5 $\mathrm{mL}$ ) was added portion wise with a pipette. The system was flushed with $\mathrm{N}_{2}$-gas closed with a screw cap and placed at $55^{\circ} \mathrm{C}$ in an aluminium heating block for $22 \mathrm{~h}$ while stirring. Then, NCS (61.5 mg, $0.461 \mathrm{mmol}$ ) was dissolved in anhydrous MeCN $(1 \mathrm{~mL})$ and added to the mixture. After a total of $26 \mathrm{~h}$ the reaction was quenched by adding the mixture to $\mathrm{KPF}_{6}(\mathrm{aq})(0.2 \mathrm{M}, 200 \mathrm{~mL})$ while stirring. The red precipitate was isolated by filtration and washed with $\mathrm{Et}_{2} \mathrm{O}(200 \mathrm{~mL})$. The precipitate was recrystallized in $\mathrm{MeOH}(30 \mathrm{~mL} / \mathrm{g})$. Yield: $612 \mathrm{mg}$ (54\%).

${ }^{1} \mathrm{H}$ NMR $\left(500 \mathrm{MHz}\right.$, Acetonitrile- $\left.d_{3}\right) \delta 8.26-8.23(\mathrm{~m}$, $2 \mathrm{H}), 7.99$ (d, $J=9.2 \mathrm{~Hz}, 2 \mathrm{H}), 7.68$ (s, 1H), 7.17 (d, $J=$ $8.0 \mathrm{~Hz}, 2 \mathrm{H}), 5.07-5.04(\mathrm{~m}, 2 \mathrm{H}), 3.64(\mathrm{~s}, 3 \mathrm{H}), 3.36(\mathrm{~s}$, $3 \mathrm{H}), 2.30-2.21(\mathrm{~m}, 2 \mathrm{H}), 1.30(\mathrm{t}, J=7.4 \mathrm{~Hz}, 3 \mathrm{H})$.

${ }^{13} \mathrm{C}$ NMR (126 MHz, $\left.\mathrm{CD}_{3} \mathrm{CN}\right) \delta 160.40(-), 153.15(-)$, 142.82(-), 141.19(+), 134.56(-), 130.81(+), 123.23(-), 120.24(-), 110.94(+), 107.96(+), 61.21(+), 57.92(+), 55.27(-), 22.13(-), 11.12(+).

One quaternary carbon signal is missing.

HRMS (MALDI-TOF) found: 486.1220. Calcd. for $\mathrm{C}_{26} \mathrm{NO}_{4} \mathrm{Cl}_{2} \mathrm{H}_{26}{ }^{+}: 486.1239$

\section{9-(3-Chloro-2,6-dimethoxyphenyl)-1,8- dimethoxy-10-propylacridinium}




\section{hexafluorophosphate}

In a dry pyrex tube $3(405 \mathrm{mg}, 0.719 \mathrm{mmol})$ was dissolved in anhydrous MeCN (5 mL) flushed with $\mathrm{N}_{2}$ gas. NCS (102 mg, $0.764 \mathrm{mmol}$ ) was dissolved in anhydrous $\mathrm{MeCN}(2 \mathrm{~mL})$ and added portion wise to the Pyrex tube. The system was then flushed with $\mathrm{N}_{2}$ gas, closed with a screw cap and left stirring at $55^{\circ} \mathrm{C}$ in an aluminium heating block. After $25 \mathrm{~h}$ the reaction was complete. The mixture was cooled to room temperature and added portion wise via pipette to $\mathrm{KPF}_{6}(\mathrm{aq})(0.2 \mathrm{M}, 350 \mathrm{~mL})$ while stirring. The fine red precipitate was isolated by filtration and washed with $\mathrm{Et}_{2} \mathrm{O}(20 \mathrm{~mL})$. No further purification was needed. Yield: $415 \mathrm{mg}$ (97\%).

${ }^{1} \mathrm{H}$ NMR $\left(500 \mathrm{MHz}\right.$, Acetonitrile- $\left.d_{3}\right) \delta 8.24-8.20(\mathrm{~m}$, $2 \mathrm{H}), 7.94(\mathrm{~d}, J=9.2 \mathrm{~Hz}, 2 \mathrm{H}), 7.51(\mathrm{~d}, J=8.9 \mathrm{~Hz}, 1 \mathrm{H})$, $7.13(\mathrm{~d}, J=8.0 \mathrm{~Hz}, 2 \mathrm{H}), 6.89(\mathrm{~d}, J=8.9 \mathrm{~Hz}, 1 \mathrm{H}), 5.05$ $-5.01(\mathrm{~m}, 2 \mathrm{H}), 3.60(\mathrm{~s}, 3 \mathrm{H}), 3.58(\mathrm{~s}, 6 \mathrm{H}), 3.28(\mathrm{~s}, 3 \mathrm{H})$, $2.27-2.19(\mathrm{~m}, 2 \mathrm{H}), 1.28(\mathrm{t}, J=7.4 \mathrm{~Hz}, 3 \mathrm{H})$.

${ }^{13} \mathrm{C}$ NMR (126 MHz, $\left.\mathrm{CD}_{3} \mathrm{CN}\right) \delta 160.96(-), 156.35(-)$, 155.49(-), 151.50(-), 142.70(-), 141.04(+), 130.50(+), 127.99(-), 120.54(-), 119.43(-), 110.60(+), 107.94(+), 107.71(+), 60.91(+), 57.80(+), 56.98(+), 55.00(-), 22.11(-), 11.11(+).

Two quaternary carbon signals are missing in the spectrum.

HRMS (MALDI-TOF) found: 452.1622. Calcd. for $\mathrm{C}_{26} \mathrm{H}_{27} \mathrm{ClNO}_{4}{ }^{+}$: 452.1629 .

\section{4-Chloro-1,13-dimethoxy-5,9-}

dipropylquinolino[2,3,4- $k l]$ acridinium hexafluorophosphate

To a Pyrex tube 5 (398 $\mathrm{mg}, 0.665 \mathrm{mmol})$ was dissolved in anhydrous $\mathrm{MeCN}(2.2 \mathrm{~mL})$. Propylamine $(0,55 \mathrm{~mL}, 7.7 \mathrm{mmol})$ was added with syringe, and the system was flushed with $\mathrm{N}_{2}$-gas. The Pyrex tube was sealed with a screw cap and placed in an aluminium heating block at $100^{\circ} \mathrm{C}$ for $2 \mathrm{~h}$ while stirring. Upon cooling the reaction mixture was added dropwise to $\mathrm{KPF}_{6}(\mathrm{aq})(0.2 \mathrm{M}$, $200 \mathrm{~mL}$ ). The precipitate was isolated by filtration and washed with $\mathrm{Et}_{2} \mathrm{O}(100 \mathrm{~mL})$. The precipitate was washed off the filter with $\mathrm{MeCN}$ and reprecipitated in $\mathrm{Et}_{2} \mathrm{O}(200 \mathrm{ml})$. The reprecipitated solid was collected by filtration and washed off filter with DCM and concentrated in vacuo. The formed solid was then recrystallized in 8:2 iPrOH/MeCN (49 mL/g). Yield: $153 \mathrm{mg}(39 \%)$.

${ }^{1} \mathrm{H}$ NMR $\left(500 \mathrm{MHz}\right.$, Acetonitrile- $\left.d_{3}\right) \delta 8.18(\mathrm{t}, J=8.4$ $\mathrm{Hz}, 1 \mathrm{H}), 8.02-7.97(\mathrm{~m}, 1 \mathrm{H}), 7.85(\mathrm{~d}, J=8.9 \mathrm{~Hz}, 1 \mathrm{H})$, $7.67(\mathrm{~d}, J=8.7 \mathrm{~Hz}, 1 \mathrm{H}), 7.61(\mathrm{~d}, 2 \mathrm{H}), 6.99(\mathrm{~d}, J=8.0$ $\mathrm{Hz}, 1 \mathrm{H}), 6.94(\mathrm{~d}, J=9.0 \mathrm{~Hz}, 1 \mathrm{H}), 5.08(\mathrm{dt}, J=14.2,7.0$ $\mathrm{Hz}, 1 \mathrm{H}), 4.79-4.70(\mathrm{~m}, 1 \mathrm{H}), 4.61-4.50(\mathrm{~m}, 2 \mathrm{H}), 3.78$ (s, 3H), 3.69 (s, 3H), $2.12-2.04(\mathrm{~m}, 2 \mathrm{H}), 1.66-1.49$ $(\mathrm{m}, 2 \mathrm{H}), 1.21(\mathrm{t}, J=7.4 \mathrm{~Hz}, 3 \mathrm{H}), 0.50(\mathrm{t}, J=7.3 \mathrm{~Hz}$, $3 \mathrm{H})$.

${ }^{13} \mathrm{C}$ NMR (126 MHz, $\left.\mathrm{CD}_{3} \mathrm{CN}\right) \delta 160.75(-), 158.18(-)$, 144.04(-), 143.14(-), 142.62(-), 141.73(-), 139.53(-), 139.20(+), 139.00(+), 137.55(+), 122.96(-), 119.60(-), 115.87(-), 115.12(-), 109.92(+), 108.82(+), 107.26(+), 107.04(+), 104.33(+), 58.48(-), 56.87(+), 56.79(+), 52.87(-), 22.86(-), 21.06(-), 11.24(+), 11.23(+).

HR-MS (ESP) found: 447.1832. Calcd. for $\mathrm{C}_{27} \mathrm{~N}_{2} \mathrm{O}_{2} \mathrm{ClH}_{27}{ }^{+}$: 447.1839 .

\section{9-(2,6-Dimethoxyphenyl)-1-methoxy-8- propylamino-10-propylacridinium} hexafluorophosphate (IM-1a): 3 (201 mg, 0.357 $\mathrm{mmol})$ was dissolved in acetonitrile $(1.2 \mathrm{~mL})$ in a pyrex reaction tube. $n$-propylamine $(0.30 \mathrm{~mL}, 3.65$ mmol) was added to the red solution, resulting in some decoloration. The reaction tube was sealed with a screw cap and placed in a heating block at $35^{\circ} \mathrm{C}$. Reaction progress was monitored by MALDI-TOF. The solution darkened with increasing reaction time. After 4.8 days around 50 $\%$ conversion of the starting material was observed by MALDI-TOF, with no progress for the past 3 days. The reaction was removed from the heating block and allowed to cool to room temperature. The dark green reaction solution was poured into $\mathrm{Et}_{2} \mathrm{O}$ under vigorous stirring and the resulting precipitate was isolated by filtration. After thorough washing with $\mathrm{Et}_{2} \mathrm{O}$, the precipitate was eluted off the filter with DCM. The solvent was subsequently evaporated under reduced pressure at $35^{\circ} \mathrm{C}$ and the product was purified by flash column chromatography (DCM-MeOH, 98:2) to give the product as a dark green solid $(65 \mathrm{mg}, 31 \%)$. The product is not completely pure, but sufficient for structural assignment and observing optical properties.

${ }^{1} \mathrm{H}$ NMR $\left(500 \mathrm{MHz}\right.$, Acetonitrile- $\left.d_{3}\right) \delta 8.07(\mathrm{dd}, J$ $=9.1,8.0 \mathrm{~Hz}, 1 \mathrm{H}), 7.99-7.93(\mathrm{~m}, 1 \mathrm{H}), 7.75(\mathrm{~d}, J$ 
$=9.1 \mathrm{~Hz}, 1 \mathrm{H}), 7.63(\mathrm{t}, J=8.5 \mathrm{~Hz}, 1 \mathrm{H}), 7.27(\mathrm{~d}, J=$ $8.8 \mathrm{~Hz}, 1 \mathrm{H}), 6.98(\mathrm{~d}, J=8.0 \mathrm{~Hz}, 1 \mathrm{H}), 6.91(\mathrm{~d}, J=$ $8.5 \mathrm{~Hz}, 2 \mathrm{H}), 6.60$ (d, $J=8.4 \mathrm{~Hz}, 1 \mathrm{H}), 5.84(\mathrm{~s} \mathrm{br}$, $1 \mathrm{H}), 4.87-4.74(\mathrm{~m}, 2 \mathrm{H}), 3.62(\mathrm{~s}, 6 \mathrm{H}), 3.47(\mathrm{~s}, 3 \mathrm{H})$, $2.92(\mathrm{td}, J=7.0,4.5 \mathrm{~Hz}, 2 \mathrm{H}), 2.17-2.10(\mathrm{~m}, 2 \mathrm{H})$, $1.33-1.13$ (m, 5H), 0.77 (t, $J=7.4 \mathrm{~Hz}, 3 \mathrm{H})$.

${ }^{13} \mathrm{C}$ NMR (126 MHz, Acetonitrile- $\left.d_{3}\right) \delta 161.2(-)$, $157.2(-), 155.3(-), 152.3(-), 143.0(-), 142.4(-)$, $142.0(+), 139.8(+), 133.2(+), 118.2(-)^{*}, 116.9(-$ ), $109.9(+), 106.8(+), 106.1(+), 105.1(+), 103.1$ $(+), 57.8(+), 57.0(+), 54.4(-), 46.8(-), 22.2(-)$, $21.4(-), 12.0(+), 11.1(+)$. "Two signals missing. Seen as cross peaks in HMBC.

HRMS (ESP): Calcd. for $\mathrm{C}_{28} \mathrm{H}_{33} \mathrm{~N}_{2} \mathrm{O}_{3}{ }^{+}\left[\mathrm{M}^{+}\right]$: 445.2491. Found: 445.2493.

\section{Conflicts of interest}

The authors declare the following competing financial interests: Bo W. Laursen is associated with the company KU-dyes, which produces and sells fluorescent dyes (including triangulenium dyes).

\section{Acknowledgements}

The work was supported by the Danish Council of Independent Research (DFF-6111-00483).

\section{References:}

1. Laursen, B. W.; Krebs, F. C., Synthesis of a triazatriangulenium salt. Angew. Chem. Int. Ed. 2000, 39 (19), 3432-3434.

2. Laursen, B. W.; Krebs, F. C.; Nielsen, M. F.; Bechgaard, K.; Christensen, J. B.; Harrit, N., 2,6,10-

Tris(dialkylamino)trioxatriangulenium ions. Synthesis, structure, and properties of exceptionally stable carbenium ions. J. Am. Chem. Soc. 1998, 120 (47), 12255-12263.

$3 . \quad B o s s o n$, J.; Gouin, J.; Lacour, J., Cationic triangulenes and helicenes: synthesis, chemical stability, optical properties and extended applications of these unusual dyes. Chem. Soc. Rev. 2014, 43 (8), 2824-40.

$4 . \quad$ Sørensen, T. J.; Rosenberg, M.; Frankær, C. G.; Laursen, B. W., An Optical pH Sensor Based on Diazaoxatriangulenium and Isopropyl-Bridged Diazatriangulenium Covalently
Bound in a Composite Sol-Gel. Adv. Mater. Technol. 2018, $O$ (0), 1800561.

$5 . \quad$ Rosenberg, M.; Laursen, B. W.;

Frankær, C. G.; Sørensen, T. J., A Fluorescence Intensity Ratiometric Fiber Optics-Based Chemical Sensor for Monitoring pH. Adv. Mater. Technol. 2018, 3 (12), 1800205.

$6 . \quad$ Dalfen, I.; Dmitriev, R. I.; Holst, G.; Klimant, I.; Borisov, S. M., Background-Free Fluorescence-Decay-Time Sensing and Imaging of $\mathrm{pH}$ with Highly Photostable

Diazaoxotriangulenium Dyes. Anal. Chem. 2019, 91 (1), 808-816.

$7 . \quad$ Gueret, R.; Poulard, L.; Oshinowo, M.; Chauvin, J.; Dahmane, M.; Dupeyre, G.; Lainé, P. P.; Fortage, J.; Collomb, M.-N., Challenging the [Ru(bpy)3]2+ Photosensitizer with a Triazatriangulenium Robust Organic Dye for Visible-Light-Driven Hydrogen Production in Water. ACS Catal. 2018, 8 (5), 3792-3802.

8. Hargenrader, G. N.; Weerasooriya, R. B.; Ilic, S.; Niklas, J.; Poluektov, O. G.; Glusac, K. D., Photoregeneration of Biomimetic Nicotinamide Adenine Dinucleotide Analogues via a Dye-Sensitized Approach. ACS Appl. Energy Mater. 2018, 2 (1), 80-91.

9. Mei, L.; Veleta, J. M.; Gianetti, T. L., Helical Carbenium Ion: A Versatile Organic Photoredox Catalyst for Red-Light-Mediated Reactions. J. Am. Chem. Soc. 2020, 142 (28), 12056-12061.

10. Maliwal, B. P.; Fudala, R.; Raut, S.;

Kokate, R.; Sørensen, T. J.; Laursen, B. W.;

Gryczynski, Z.; Gryczynski, I., Long-Lived Bright

Red Emitting Azaoxa-Triangulenium

Fluorophores. PLOS ONE 2013, 8 (5), e63043.

11. Rich, R. M.; Stankowska, D. L.;

Maliwal, B. P.; Sorensen, T. J.; Laursen, B. W.;

Krishnamoorthy, R. R.; Gryczynski, Z.; Borejdo, J.; Gryczynski, I.; Fudala, R., Elimination of autofluorescence background from fluorescence tissue images by use of time-gated detection and the AzaDiOxaTriAngulenium (ADOTA) fluorophore. Anal. Bioanal. Chem. 2013, 405 (6), 2065-2075.

12. Sørensen, T. J.; Thyrhaug, E.; Szabelski, M.; Luchowski, R.; Gryczynski, I.; Gryczynski, Z.; Laursen, B. W.,

Azadioxatriangulenium: a long fluorescence lifetime fluorophore for large biomolecule 
binding assay. METHODS Appl. Fluores. 2013, 1 (2), 025001.

13. Laursen, B. W.; Bogh, S. A.;

Sørensen, T. J., Chapter Twelve - Long fluorescence lifetime triangulenium dyes in imaging and fluorescence polarization assay. In Methods in Enzymology, Chenoweth, D. M., Ed. Academic Press: 2020; Vol. 640, pp 249-265.

14. Thyrhaug, E.; Sørensen, T. J.; Gryczynski, I.; Gryczynski, Z.; Laursen, B. W., Polarization and Symmetry of Electronic Transitions in Long Fluorescence Lifetime Triangulenium Dyes. Am. J. Phys. Chem. 2013, 117 (10), 2160-2168.

$15 . \quad$ Bogh, S. A.; Simmermacher, M.; Westberg, M.; Bregnhøj, M.; Rosenberg, M.; De Vico, L.; Veiga, M.; Laursen, B. W.; Ogilby, P. R.; Sauer, S. P. A.; Sørensen, T. J.,

Azadioxatriangulenium and Diazaoxatriangulenium: Quantum Yields and Fundamental Photophysical Properties. ACS Omega 2017, 2 (1), 193-203.

$16 . \quad$ Rosenberg, M.; Rostgaard, K. R.; Liao, Z.; Madsen, A. O.; Martinez, K. L.; Vosch, T.; Laursen, B. W., Design, synthesis, and time-gated cell imaging of carbon-bridged triangulenium dyes with long fluorescence lifetime and red emission. Chem. Sci. 2018, 9 (12), 3122-3130. $17 . \quad$ Rosenberg, M.; Santella, M.; Bogh, S. A.; Muñoz, A. V.; Andersen, H. O. B.; Hammerich, O.; Bora, I.; Lincke, K.; Laursen, B. W., Extended Triangulenium lons: Syntheses and Characterization of Benzo-Bridged Dioxa- and Diazatriangulenium Dyes. J. Org. Chem. 2019, 84 (5), 2556-2567.

$18 . \quad$ Delgado, I. H.; Pascal, S.; Besnard, C.; Voci, S.; Bouffier, L.; Sojic, N.; Lacour, J., CFunctionalized Cationic Diazaoxatriangulenes: Late-Stage Synthesis and Tuning of Physicochemical Properties. Chem. Eur. J. 2018, 24, 10186-10195.

$19 . \quad$ Delgado, I. H.; Pascal, S.; Wallabregue, A.; Duwald, R.; Besnard, C.; Guenee, L.; Nancoz, C.; Vauthey, E.; Tovar, R. C.; Lunkley, J. L.; Muller, G.; Lacour, J., Functionalized cationic 4 helicenes with unique tuning of absorption, fluorescence and chiroptical properties up to the far-red range. Chem. Sci. 2016, 7 (7), 4685-4693.
20. Laursen, B. W.; Krebs, F. C., Synthesis, structure, and properties of azatriangulenium salts. Chem. Eur. J. 2001, 7 (8), 1773-1783.

21. Laleu, B.; Herse, C.; Laursen, B. W.; Bernardinelli, G.; Lacour, J., Bent structure and dynamic stereochemistry of chiral acridinium cations. J. Org. Chem. 2003, 68 (16), 6304-6308. $22 . \quad$ Nicolas, C.; Herse, C.; Lacour, J., Catalytic aerobic photooxidation of primary benzylic amines using hindered acridinium salts. Tetrahedron Lett. 2005, 46 (27), 4605-4608.

23. Labrador, G. M.; Besnard, C.; Bürgi, T.; Poblador-Bahamonde, A. I.; Bosson, J.; Lacour, J., Stereochemical significance of $\mathrm{O}$ to $\mathrm{N}$ atom interchanges within cationic helicenes: experimental and computational evidence of near racemization to remarkable enantiospecificity. Chem. Sci. 2019, 10 (29), 70597067.

$24 . \quad$ Murov, S. L.; Carmichael, I.; Hug, G. L., Handbook of Photochemistry. 2nd ed.; Marcel Dekker: 1993.

$25 . \quad$ Bogh, S. A.; Simmermacher, M.; Westberg, M.; Bregnhoj, M.; Rosenberg, M.; De Vico, L.; Veiga, M.; Laursen, B. W.; Ogilby, P. R.; Sauer, S. P. A.; Sørensen, T. J., Azadioxatriangulenium and Diazaoxatriangulenium: Quantum Yields and Fundamental Photophysical Properties. Acs Omega 2017, 2 (1), 193-203.

26. Adam, C.; Wallabregue, A.; Li, H. D.; Gouin, J.; Vanel, R.; Grass, S.; Bosson, J.; Bouffier, L.; Lacour, J.; Sojic, N., Electrogenerated Chemiluminescence of Cationic Triangulene Dyes: Crucial Influence of the Core Heteroatoms (vol 21, 2015, 19243-19249). Chem. Eur. J. 2019, 25 (30), 7402-7402.

$27 . \quad$ Ilic, S.; Pandey Kadel, U.; Basdogan, Y.; Keith, J. A.; Glusac, K. D., Thermodynamic Hydricities of Biomimetic Organic Hydride Donors. J. Am. Chem. Soc. 2018, 140 (13), 45694579.

$28 . \quad$ Krebs, F. C.; Spanggaard, H.; Rozlosnik, N.; Larsen, N. B.; Jørgensen, M., Synthesis, Properties, and Langmuir-Blodgett Film Studies of an Ionic Dye Terminated Rigid Conducting Oligomer. Langmuir 2003, 19 (19), 7873-7880. 
29.

Hammershøj, P.; Sørensen, T. J.;

Han, B.-H.; Laursen, B. W., Base-Assisted One-Pot Synthesis of $\mathrm{N}, \mathrm{N}^{\prime}, \mathrm{N}^{\prime \prime}$-Triaryltriazatriangulenium

Dyes: Enhanced Fluorescence Efficiency by Steric Constraints. J. Org. Chem. 2012, 77, 5606-5612

30.

Voci, S.; Duwald, R.; Grass, S.;

Hayne, D. J.; Bouffier, L.; Francis, P. S.; Lacour, J.;

Sojic, N., Self-enhanced multicolor

electrochemiluminescence by competitive electron-transfer processes. Chem. Sci. 2020, 11 (17), 4508-4515.

31. Magde, D.; Wong, R.; Seybold, P. G., Fluorescence Quantum Yields and Their Relation to Lifetimes of Rhodamine $6 \mathrm{G}$ and Fluorescein in Nine Solvents: Improved Absolute Standards for Quantum Yields. Photochem. Photobiol. 2002, 75 (4), 327-334. 